\title{
Kitle İletişim Araçlarının Çocukların Algısına Etkisi: 15 Temmuz Örneği
}

\author{
The Effect of the Mass Media on the Perception of Children: 15 July Case
}

\section{Rengim SINNE NAZLI* Gülşah SARI ${ }^{* *}$}

Öz

Çocuklar gerek kitle iletişim araçları gerekse sosyal çevrelerinden çeşitli mesajlara maruz kalmaktadır. Çocukların dünyayı algılayış şekilleri de aldıkları bu mesajlarla belirlenmektedir. Bu çalışmada, çocukların 15 Temmuz 2016'da yaşanan darbe girişiminden gerek kitle iletişim araçları gerekse sosyal çevreleri aracılığıyla zihinlerinde nasıl bir algı oluştuğunu tespit etmek adına İstanbul ve Trabzon illerinde yaşayan, 3. ve 4. sınıfta okuyan 351 öğrenciye 15 Temmuz konulu resimler çizdirilmiştir. Yapılan resimler incelenerek "çatışmaya karşı koyan halk", "saldırıya uğrayan halk", "milli birlik ve beraberlik", "simge noktaları", "kutlama, zafer” ve "dini öğeler” şeklinde altı başlık altında kategorilendirilmiştir. Elde edilen resimler sonucunda çocukların kitle iletişim araçları ve sosyal çevrelerinden algıladıklarını çizdikleri resimlerle açığa çıkardıkları tespit edilirken, çocukların 15 Temmuz’u milli birlik ve beraberlik, bayrak, tank, kahramanlık gibi temalarla resmettiği tespit edilmiştir.

Anahtar kelimeler: Kitle İletişim Araçları, Çocuk, Resim, Mesaj, 15 Temmuz Darbe Girişimi, Alımlama

\begin{abstract}
Children are exposed to a variety of messages from both the mass media and their social environments. The way they perceive the world is determined by the messages they receive. In this study, in order to find out what kind of perception has occurred in the minds of the children both by the effect of mass media and their social circles after the coup attempt, 351 students studying in the third and forth grade of the primary school and living in the provinces of Istanbul and Trabzon were asked to draw with the theme of the July 15th. The drawings have been categorized under six headings: "People fighting against armed conflict",

* Dr. Öğr. Üye., Bolu Abant İzzet Baysal Üniversitesi, İletişim Fakültesi, Bolu, Türkiye, rengimsine@ibu.edu.tr, Orcid ID: 0000-0002-8776-8922

** Dr. Öğr. Üye., Bolu Abant İzzet Baysal Üniversitesi, İletişim Fakültesi, Bolu, Türkiye, gulsah.sari@ibu.edu.tr, Orcid ID: 0000-0001-6590-6530
\end{abstract}


people who are attacked", "National unity and togetherness", "Symbol points", "Celebration, victory" and "Religious items". As a result of the paintings, it was determined that children were exposed to the images they perceived from the mass media and their social circles, and that the children depicted July 15th with themes such as national unity and solidarity, flag, tank, heroism.

Keywords: Mass Media, Child, Picture, Message, 15th July Coup Attempt, Reception

\section{Giriş}

Yaşadığımız yüzyılda küçük yaşta kitle iletişim araçlarıyla tanışan çocuk, bu durumdan olumlu veya olumsuz yönde etkilenebilmektedir. Çocuklar yaşadığ 1 dünyaya dair düşüncelerinin önemli bir kısmını kitle iletişim araçlarından öğrenmektedir. Nitekim öğrenme; aile, okul, kültürel yapı ve coğrafyayı içeren geniş bir konudur (Tombul, 2018, s. 119). Bununla birlikte Neil Postman, 1995 yılında yayınlanan Çocukluğun Yokoluşu isimli kitabında iletişim araçlarından özellikle televizyonla yetişkinler ve çocuklar arasındaki çizginin aşındığını belirtmektedir (Postman, 1995, s. 104). Böyle bir ortamda ise çocukların yetişkinlere yönelik haber içeriklerine maruz kalma ihtimali ön plana çıkmaktadır.

Yetişkinlere yönelik televizyon içeriklerine maruz kalan çocukların çoğu, algılama düzeyleri gereği televizyonda gördüklerini gerçek sanmaktadırlar. Belli bir algılama düzeyine erişilmeden izlenen içerikler, çocuğa yanlış kavramlar ve çağrışımlarla olumsuz etki yapabilmektedir (Öcel, 2002, s. 282). Sadece Türk halkı değil, bütün dünya için tarihi bir olay olan 15 Temmuz 2016 Darbe Girişimi de, toplumun her kesimini derinden etkilemiştir. Dolayısıyla bu olay, beraberinde çeşitli sosyo-psikolojik etkiler de getirmiştir. Bu çalışmada, 15 Temmuz Darbe Girişimi’nin çocukların zihninde nasıl bir etki bıraktığı tespit edilmeye çalışılmaktadır. Bahsi geçen etkinin tespiti için çalışmada resimleme yöntemi tercih edilmiştir. Nitekim Türkiye’de yapılan çeşitli çalışmalarda çocukların şiddet, medya, reklam gibi kavramları nasıl algıladıkları da çizdikleri resimler aracılığıyla ortaya konmuştur. Aşina Gülerarslan’ın (2014) da belirttiği gibi çocuklar, günümüzde toplumsal yaşamdan ayrı düşünülmesi mümkün olmayan medya aracılığıyla, gönderilen her türlü görsel ve işitsel bilginin bombardımanı altındadır. Çocuklar, karşılaştıkları görsel uyarıcıları deşifre etmekte ve sosyal yaşamla ilişkilendirilmektedir. Resimleme de iç ve dış dünyadaki tüm uyarıcıların deşifre edilme biçimi olarak görülebilmektedir (s. 137).

Öte yandan 15 Temmuz Darbe Girişimi, kitle iletişim araçlarından izleyicilere ya da okuyuculara aktarılırken çeşitli görseller ön plana çıkarılmıştır. Olayların çerçevelenmesinde temel belirleyicilerin etrafında şekillenen bu görüntüler, 15 Temmuz Darbe Girişimi’ni temsil etmelerinin yanı sıra kitle iletişim araçlarının da etkisiyle zihinlere kazınmıştır. 15 Temmuz Darbe Girişimi’ni tanımlayan görüntülerden en belirginleri bayrak, asker, sivil halkın tankların önüne geçmesi ile Şehit Astsubay Kıdemli Başçavuş Ömer Halisdemir'in de içinde bulunduğu karelerden oluşmaktadır. Hangi coğrafyada olduğu fark etmeksizin, yaşadığı toplumda gerek toplumun gereksekitle iletişim araçlarının oluşturduğu çerçeveler içinde bulunmaya mahkûm olan çocukların, maruz kaldığı uyarıcıların zihinlerinde yer ettiği ve çevrelerinde gelişen olayları bu çerçeveden algıladıkları varsayımı bu çalışmaya temel oluşturmaktadır. Çalışmada tercih edilen resimleme yöntemi aracılığıyla İstanbul ve 
Trabzon illerinde 3. ve 4. sınıflarda okuyan 351 öğrencinin zihninde 15 Temmuz Darbe Girişimi’nin nasıl bir yer edindiği tespit edilmeye çalışılmıştır.

\section{Kitle İletişim Araçları ve Toplumsal Etkileri}

Tarihin başlangıcından bu yana insanların hayatlarını idame ettirebilmeleri için gerekli en temel unsurlardan biri şüphesiz iletişimdir. İletişimin tüm topluma veya çoğunluğunun alıcı konumunda olduğu gruba yönelik şekli ise kitle iletişimi olarak tanımlanmaktadır (Bektaş, 2000, s. 15). Yüz yüze iletişimde olduğu gibi karşılıklı olmaya gerek kalmadan anında iletişim kurulmasını sağlayan ve bunu kitlesel düzeyde gerçekleştiren araçlara da kitle iletişim araçları denmektedir (Türkoğlu, 2010, s. 69). Geleneksel iletişim şekli olan yüz yüze ve sınırlı iletişimin kimi zaman yetersiz kalması insanoğlunu daha yaygın, daha hızlı, daha kolay ve daha etkin iletişim kurmanın yollarını aramaya itmiştir. İşte bu gereksinime yanıt vermek üzere, özel araçların geliştirilmesi sonucunda kitle iletişim araçları ortaya çıkmıştır (Balcı ve Gergin, 2008, s. 146-147).

Kitle toplumunda bireyler bilgilenmek için kitle iletişim araçlarına başvurmaktadır. Bu bağlamda kitle iletişim araçları, tüm toplum hayatına gözcülük yapmakta, bilgilerin bir merkezde toplanması ve bu merkezden bireylere dağıtılmasına yardımcı olmaktadır (Yıldız, 2017, s. 9). Kitle iletişim araçları bireylerin toplumsallaşmasında da önemli rol oynamaktadır. Bilindiği gibi toplumsallaşma ilk olarak ailede başlar. Bireyin sosyalleşmesi eğitim-öğretim kurumlarında devam eder. Birey, toplumsallaşmasında birçok farklı faktörün etkisi altındadır. Aile ve okul kadar kitle iletişim araçları da bireyin toplumsallaşmasında oldukça belirgin bir yer tutmaktadır. Sinema, televizyon, tiyatro, gazete ve kitap gibi kitle iletişim aygıtlarının da günümüzde bireylerin toplumsallaşmasında oldukça etkili araçlar olduğu bilinmektedir (Taylan, 2011, s. 14).

Dolayısıyla kitle iletişim araçlarının temel özelliği, insanların düşüncelerini etkileyerek toplumda ortak bir bilinç yaratmak ve bu bilinci yeni nesillere aktarmaktır. Kitle iletişim araçları toplumun yaşam tarzını gençlere ileterek onların toplumsallaşmasında önemli rol oynamaktadır. Kitle iletişim araçları toplumsal uzlaşmayı sağlamada hayati bir rol oynamasının yanında sosyal hayatta cereyan eden tüm olayları kendi merceğinden değerlendirerek kitlelere aktarmaktadır (Taylan, 2011, s. 14-15). Yani kar amaçlı ticari kurum olan medya organları, haber değeri olan olayları kendi ekonomik veya ideolojik çıkarları ekseninde kitlelere aktarmaktadır. Bir başka deyişle, sosyal hayatta cereyan eden tüm olaylar, medyanın kendi bakışıyla değerlendirildikten sonra kitlelere ulaşmaktadır. "Kitle iletişim araçlarının insanlara ne yaptığı sorusu” iletişim araştırmalarının en çok üzerinde durduğu konuların başında gelmektedir. Bu alanda yapılan çalışmaların temel sorusu medya aracılığıyla sunulan içeriklerin, bu içeriklerin alıcılarının düşüncelerini nasıl biçimlendirdiği, insanların dikkatlerini hangi konulara ve olaylara çektiği ve medya içeriklerinin insanların tutum ve alışkanlıklarını etkileyerek insanları ne tür tutum ve davranışlar geliştirmeye ittiğidir (Yaylagül, 2008, s. 39).

Kitle iletişim araçları şüphesiz, akademik araştırmaların hedefi haline gelebilecek birçok sosyal fonksiyona hizmet etmektedir. Bunlardan üç tanesinden söz etmek gerekirse; ilkin kitle iletişim araçları kamusal meseleler, kişiler, örgütler ve sosyal hareketler hakkında görüş bildirmektedir. Örneğin, The Times'ın politik bir adaya verdiği destek, politik aday için bir ayrıcalık olarak kabul edilmektedir. 
Çünkü kimilerine göre The Times'ın görüşleri bir grup uzmanın değerlendirilmiş yargısını temsil eder ve bu nedenle saygı gerektirmektedir. İkincisi, sosyal normların uygulanması hakkındadır. Kitle iletişim araçları, kamusal ahlakla çelişen koşulları "açığa çıkararak" örgütlenmiş toplumsal eylemi başlatabilmektedir. Kitle iletişim araçlarının üçüncü fonksiyonu ise büyük oranda fark edilmemiştir. En azından, çok az açık bir yorum almış ve görünüşe göre, planlı hedefleri geliştirmek için sistematik olarak kullanılmamıştır. Bu fonksiyon, kitle iletişim araçlarının uyuşturucu işlevi olarak adlandırılabilir. Siyasi olarak ilgisiz olan geniş kitleler halindeki nüfus, modern toplumun çıkarına dayanmadığı varsayımı üzerine işlevsizdir (Lazarsfeld ve Merton, 2007, s. 235-238).

$\mathrm{Bu}$ denli sosyal fonksiyonlara sahip ve insanın toplumsallaşmasında önem taşıyan kitle iletişim araçlarının etkileriyle ilgili araştırmalar genel olarak üç dönemde toplanmıştır. Bunlar güçlü etkiler, sınırlı etkiler ve güçlü etkilere geri dönüş dönemi olarak ele alınmaktadır. 1910'dan 1940'lı yıllara kadarki süreci kapsayan güçlü etkiler döneminde yapılan araştırmalar sonucunda geliştirilen sihirli mermi kuramı kitle iletişiminin etkileriyle ilgili ilk kavramlardan biridir (Işık, 2017, s. 86-87). Ayrıca hipodermik iğne kuramı, iletim kuramı ya da şırınga modeli olarak da bilinmektedir. Sihirli mermi kuramı, iletişim araçlarının güçlü, anında ve doğrudan etkileri olduğunu varsayar. Sihirli mermi kuramına temel olan iletişim araçlarının güçlü etkileri görüşü, I. Dünya Savaşı’nda propagandanın güçlü görünümünden etkilenmiştir (Tekinalp ve Uzun, 2013, s. 115). Sihirli mermi metaforu, siyasal iletişim, propaganda ve psikolojik savaş anlamına oldukça uymaktadır. Siyasal kampanyada ileti nüfus içine yayılır ve birçok kişide görülebilir bir etki yapmadan geçer; fakat etki, siyasal yönelim arayan belli azınlığın mevcut gereksinimleriyle iletinin içeriği uyuştuğu zaman ortaya çımaktadır. Yani sihir, merminin bütün insanlara etki yapmaksızın geçmesinde gizlenmiştir (Erdoğan ve Alemdar, 2005, s. 59-60).

İkinci dönem olan sınırlı etkiler dönemi, 1930 'lu yılların sonları ile 1960 'l y yllara kadar olan dönemi kapsamaktadır. Kitle iletişim araçlarının ABD'de yaygınlaştığı 1930'lu yılların sonlarına doğru kitle iletişim araştırmaları "etki” konusuna yoğunlaşmıştır (Iş̧1k, 2017, s. 88). 1940-1960 yılları arasında, kişilerin seçimlerinden kişilerin etkilerine, Paul Lazarsfeld ve arkadaşları, seçimlerde oy verme, satın alma, sinemaya gitme ya da bir fikrin değiştirilmesi gibi kararların verilmesinde kitle iletiş̧iminin rolüne ilişkin bir dizi panel çalışması yürütmüşlerdir. Karar verme hakkındaki çalışmalarda varılan sonuçlar, medyanın etkilerinin dikkat, algı ve hatırlamadaki seçicilik süreçleriyle azaltıldığı ve bunların yaş, aile tarihi, politik bağlantı, vb. belirleyici ve durumsal değişkenlerin bir fonksiyonu olduğu ortaya çıkmıştır (Aktaran Katz, 1987, s. 26). 1940 başkanlık seçim kampanyasında Ohioda radyo ve yazılı basının oy verme kararları üzerindeki etkisi, incelenmiştir. Bu çalışmanın bulguları, kitle iletişim araçlarının etkisinin kişisel etkilerin rolüyle karşılaştırıldığında küçük olduğunu göstermiştir. Seçmenler, kararlarını sosyal çevrelerinin politik iklimine uyum sağlayacak şekilde oluşturmuşlardır (Katz ve Lazarsfeld, 2007, s. 273). Yaylagül'ün (2008) de belirttiği gibi

Columbia Üniversitesi araştırmaları, benzer şekilde medyanın, insanların mevcut inançlarını güçlendirdiğini ortaya koymuştur. Medyanın oy verme davranışı üzerindeki etkisini onlar “iki aşamalı akış”a bağlamışlardır. Bu modele göre kamuoyu önderleri enformasyonu medyadan alarak kendi düşünce süzgeçlerinden geçirdikten sonra oy verecek gruba aktarmaktadırlar. (s. 43) 
Genel olarak iletişimin sınırlı etkilerinin olduğuna inanılan dönemde iletişimin kamuoyu üzerinde bir etki olarak etkinliği, iletişimin doğasına göre değiştiği savunulmuştur. Yani medya ne kadar kişisel olursa, fikirleri dönüştürmede o kadar etkili olmaktadır. Bu durum kişisel konuşmanın bir radyo konuşmasından daha etkili olduğu ve bir radyo konuşmasının da bir gazeteden daha etkili olduğu anlamına gelmektedir (Berelson, 2007, s. 204). Üçüncü dönem olan güçlü etkilere geri dönüş dönemi ise $1960^{\prime} l ı$ yllardan itibaren görülmektedir. Kitle iletişim araçlarının birey ve toplum üzerindeki etkileri konusunda 1960 'lı yllardan itibaren yapılan araştırmalarda, özellikle "tutum" kavramı üzerinde odaklanıldığı görülmektedir. Söz konusu araştırmalar sonucunda kitle iletişim araçlarının bireyleri etkilemede bir takım sınırlılıkları olduğu ortaya konmuştur (Işık, 2017, s. 89).

\section{Kültürel Çalışmalar Bağlamında Çocuk ve Alımlama}

Kitle iletişim araçları vasıtasıyla topluma yayılan kitle kültürünün birincil hedefi kitle insanıdır. Kitlelerin bütünden ayrılarak yalnızlaştırıldığ 1 kitle toplumunda üretilen değer ve düşüncelerin hepsi kitle kültürünü oluşturur. Kitle kültürü içinde yaşayan insanın kitle haline getirilmesinde etkili olan kitle iletişim araçlarının, bireyleri anonimleștirerek kolaylıkla yönlendirilebilecek bir toplum yaratılmasına katkıda bulunduğu savunulmaktadır (Korkmaz ve Yaylagül, 2008, s. 129). Adorno ve Horkheimer, popüler kültür ya da kitle kültürü kavramsallaştırmalarından çok kültür endüstrisi terimi üzerinde durmuşlardır (Aktaran Yaylagül, 2008, s. 143).

Kültür endüstrisi ürünlerinin birbirlerine benzeyip özgünlükten yoksun olduğunu ileri süren bu görüşte kültür tüketicisi olan kitle insanının, kitle kültürünün aracı olarak yorum yapma yeteneğini kaybettiği kabul edilmektedir (Atiker, 1998, s. 52). Ancak Birmingham Kültürel Çalışmalar Merkezinnin kurucu üyesi olan Stuart Hall, kitle iletişim araçlarının insan davranışı üzerindeki ölçülebilir etkisi üzerine yapmış olduğu çalışmalarında "medyanın görece zararsız olduğu, çoğulcu bir toplumun norm ve değerlerini pekiştirdiği” sonucuna varmıştır (Aktaran Stevenson, 2008, s. 69).

1960’n başından 1980’lere kadar uzanan klasik dönem İngiliz Kültürel Çalışmaları, kültürel çalışmalarda Marksist yaklaşımı benimsemiş, özellikle Stuart Hall, Louis Althusser ve Antonio Gramsciden etkilenmiştir (Kellner, 2016, s. 141). Hall'un "Kodlama/Kod Açımı (Encoding/ Decoding)" makalesi kültürel çalışmalar geleneğine bağlı araştırmacılar için temel teşkil etmiştir (Stevenson, 2008, s. 34). Stuart Hall bu makalesinde, “üretim-dağıtım" ve "tüketim-üretim"i kapsayan döngünün eklemlerini izlemek için Marx’ın Ekonomi Modelini (Grundrisse) kullanmıştır. Hall, bu modeli medya kurumlarının ürettiği anlamlara, bu anlamları nasıl yaydığına ve kitlelerin üretilen bu anlamları nasıl kullandığına-çözümlediğine odaklanarak somutlaştırmıştır (Halldan akt. Kellner, 2016, s. 144).

Hall, bahsi geçen makalesinde medya mesajlarının üretim, dolaşım, tüketim çemberinde yerini değerlendirerek yeni bir iletişim teorisi oluşturmayı hedeflemiştir. Zira o zamana dek izleyiciler iletişim kuramlarında pasif kuramlarında değerlendirilen izleyicinin verilen mesajları farklı şekillerde alabileceğini gözler önüne sermeyi amaçlamıştır (Halifeoğlu, 2015, s. 249). Bu bağlamda medyanın etkilerinden söz edilirken kültürel çalışmalar geleneği öncülügünde tüketicilerin medya 
mesajlarını nasıl alımladığı sorgulanmaya başlanmıştır. Böylelikle Birmingham’daki araştırmacılar kitle iletişim çalışmalarına yapısalcılığı tanıştırmışlardır (Pasquierden akt. Şakı Aydın, 2007, s. 120).

Hall'ün savunduğu iletişim sürecinde kodlama ve kodaçımı mevcuttur. Alımlamanın temelini oluşturan bu süreçte medya metinleri üç temel okuma üzerinden alımlanır. Bunlar "hakim okuma", muhalif okuma ve müzakereci okuma'dır. (Hall, 2003, s. 321-325). Egemen, müzakereli ve karşıt okuma biçimleri Hall’un Parking'den alıp geliştirdiği kavramlardır (İnal, 1996, s. 156-157).

Hall, egemen, müzakereli ve karşıt okuma konumlandırmasıyla bu anlam üretimini farklı okuma türlerine göre açıklamıștır. Egemen okumada mesajın üreticisi, herhangi bir söylemsel örnekte, bir kişinin çevresinin ayırdında olmasını sağlayan parçaları sürekli düzenler, sınırları yeniden çizer. Egemen bakış açısı ilk olarak, terimleriyle bir toplum ya da kültürdeki bütün ilişkiler kesitinin olası anlamlarının zihni ufkunu, evrenini tanımlar. İkincisi ise meşruluk mührünü taşır-toplumsal düzenle ilgili "doğal", "kaçınılmaz", "kabul edilmiş" ne varsa onunla sınırdaştır. Müzakereli okumada ise uyumlu ve karşıt elementlerin bir karışımını içermektedir. Son olarak, izleyicinin söylemi harfi ve yan anlamsal olarak mükemmel bir şekilde anlaması ama mesajı aksi yönde kod açımlaması mümkündür. Kişinin mesajın bütüncüllügünü bozarak tercih ettiği kodla, alternatif bir referans çerçevesi içinde yeniden kurmasına "karşıt okuma" denmektedir (Hall, 2005, s. 95-97).

Hall (1999) "Kodlama /Kod Açımı" adlı çalışmasında mesajların izleyiciler tarafından alınması ve mesajların yapılmasının aynı olmadığı ancak birbirleriyle ilişki içinde olduğunu; iletişim sürecinin de bir bütün olarak sosyal ilişkilerinin oluşturduğunu ifade etmektedir (s. 93). Öte yandan bir insanın herhangi bir eyleme geçebilmesi için öncelikle o yönde bir seçeneğin var olduğunu bilmesi ve bu bilgiyi algılaması gerekmektedir. Bu sebeple algılama yüzyıllardır felsefeci ve bilim insanlarının başlıca ilgi alanlarından biri olmuştur. İnsanın dış dünyadaki soyut ve somut nesnelerle kurduğu ilişki, bu nesneler hakkında bir takım yargılarda bulunması, nesnelere ilişkin bir davranış benimsemesi duyu organlarının bu nesnelerle ilgili ilettiği mesajlar aracıllğıyla şekillenmektedir (Tekinalp ve Uzun, 2013, s. 74).

\section{Kitle İletişim Araçlarının Çocuklar Üzerine Etkileri}

Kitle iletişim araçlarının ürettiği mesajların en küçük ve savunmasız tüketicisi olan çocuk, hayata dair bir takım bilgiler edinerek edindiği bu bilgileri zihinsel temsillere dönüştürüp aktif bir özne olarak sosyal yaşamda yer almaktadır. Çocuğun bilgi edinme, benlik temsili ve öğrenme sürecinde medya aktif rol oynamaktadır. Kitle iletişim araçlarının eğitim işlevi de göz önünde bulundurulduğunda, çocuğun medya ile etkileşiminin algılarına, dünya görüşlerine, tutum ve davranışlarına yön verdiği aşikârdır. Çocuk, özne olarak medyayla olan etkileşiminde kendi temsillerini üretip, yaşadığı dünyaya dair bilgileri özümserken bu bilgileri dönüştürüp sahiplenir (Yetim ve Yetim, 2008, s. 108).

Katherine E. Buckley ve Craig A. Anderson’a göre "Genel Öğrenme Modeli” medya temelli deneyimlerin, insanların veya grupların tipik karakterleri ve davranışsal senaryoları dahil olmak üzere, kullanıcıların bilgi yapılarına katkıda bulunduğunu ileri sürmektedir (Akt. Mares ve Kretz, 2015) yaşadığı dünyayı tanıma, anlama, yorumlama ve ayırt etme becerisini çocuk yaşlarda geliştirmeye başlayan insan, duyu organlarını harekete geçiren ses, görüntü, renk, tat, vb. gibi her türlü uyarıcıyı 
bilgiye dönüştürerek "dışarıya" ait zihinsel bir tasarım meydana getirmektedir (Gülerarslan, 2014, s. 133). Yani seyir esnasında, bir programın ya da programdaki diziler ve sahnelerin zihinsel temsilleri, izleyicinin bilişsel yapısı içinde yaratılmaktadır (Şeker ve Balcı, 2013, s. 253).

Yaşama ilişkin her türden bilginin çerçevelendiği mental bir üretim ve yorumlama eylemi olan anlamlandırma, dış gerçeğe yönelik içsel bir yanıttır ve esasen alıının zihninde gerçekleşmektedir (Shimp’ten akt. Gülerarslan, 2014, s. 133). Çocukların anlamlandırdıkları medyayı tespit edebilmek için son zamanlarda resim çizimi yöntemi tercih edilmektedir. Örneğin, Tülay Şeker ve Rengim Sine’nin (2012) "Çocuk Zihninde Haber Resmi” adlı çalışmalarında, Konya ilindeki 7-13 yaş grubu öğrencilere "Haber nedir?" sorusunu resim olarak çizdirmiş ve çocukların haberlerin verdikleri mesajlardan ne şekilde etkilendikleri tespit edilmeye çalışılmıştır. Çalışmanın sonucunda çocukların yaptıkları resimler doğrultusunda televizyon haberlerinin diğer haberlere oranla çocukları daha çok etkilediğini ortaya koymuştur (s. 135). Benzer şekilde Fadime Şimşek İşliyen ve Mustafa İşliyen (2015), çocukların medyayı nasıl algıladıklarını tespit etmek için “Medya nedir?” sorusunu Nevşehir ilindeki 8-9 yaş aralığındaki çocuklara resim yoluyla çizdirip belirlemeye çalışmıştır. Çalışmada, çocukların medya içeriklerini kendine göre anlamlandırıp bilgi toplamak ve haber almak için bilinçli bir şekilde medya araçlarını kullandıklarını tespit etmişlerdir (s. 286). Çocuklara resim çizdirme yöntemiyle çocukların medya algısını ölçmeye çalışan bir diğer araştırma da Filiz Yurtal ve Kazım Artut’a (2008) aittir. Yurtal ve Artut'un "Çocukların Şiddeti Algılaması ve Resim” adlı çalışmalarında, 11-12 yaş grubundaki 77 çocuğa tanık oldukları ve duydukları bir şiddet olayını çizmeleri istenmiştir. Çizilen resimler sonucunda çocukların en fazla aile içi şiddeti konu alan çizimler yaptıklarını ortaya koymuştur (s. 151-154). Gül Tuncel ve Gülhan Gürsoylar (2017) da, "Sosyal Bilgiler Dersinde Öğrencilerin Gözüyle Medya: Sanat Temelli Bir Araştırma" adlı makalelerinde İstanbul ilinde yaşayan 13 yaşındaki 66 öğrenciden medya algılarını çizmeleri istemişlerdir. Öğrencilerin çizimleri sonucunda yetişkin medyasının öğrenci algısını kuşattığını ve en çok da haber programlarını izledikleri sonucuna ulaşmışlardır (s. 672).

Kitle iletişim araçlarının çocuklara etkisi konusunda yapılan çalışmalar resimleme yöntemiyle sınırlı değildir. Özellikle televizyonun, gerek çocukların gerekse yetişkinlerin hayatında önemli bir yer edinmesinin ardından kitle iletişim araçlarının etkilerine yönelik çeşitli çalışmalar yapılmaya başlanmıştır. Amerika Birleşik Devletleri'nde 1970'lerde yapılan çalışmalara göre çocukların ve ergenlerin televizyon izlemelerinin nedenleri altı başlıkta özetlenmiştir. Araştırmaya göre çocuklar ve ergenlerin televizyonu öğrenme için, alışkanlık/zaman geçirmek, arkadaşlık, kaçış, uyarılma ve rahatlama için izlediği sonucuna varılmıştır (Rubin'den akt. Rubin, 2009, s. 531).

Yine William H. Dietz Jr. ve Steven L. Gortmaker'ın 1985 yılında yaptıkları bir araştırmaya göre televizyon ile çocukların davranışları arasındaki ilişkinin, çocukların televizyon karşısında çok zaman geçirmesiyle ilgili olduğu sonucuna ulaşılmıştır. (Amerika'da 1982'de yapılan araştırmaya göre 6-11 yaş aralığındaki çocuklar haftada 24 saati televizyon başında geçirmektedir.) Yapılan araştırmada, haftalık televizyon izleme süresi ile çocukların okul performansı arasında ters orantı olduğunu tespit edilmiştir. Aynı araştırmada çocukların televizyon izlemesinin aynı zamanda televizyonda reklamı yapılan yiyeceklerin tüketimi ve çocukların annelerinin yemek alımlarını etkileme çabaları arasında ilişki olduğu da tespit edilmiştir (s. 807). 
Anne-Claude, Bernard-Bonnin, Elizabeth Rouseau, Pierre Masson, Sophire Gilbert ve Brigitte Maheux'un (1991) televizyonun 3-10 yaş grubuna yönelik ilişkisi üzerine yaptığı araştırmaya göre, eğitim seviyesi düşük ailelerin okul öncesi çocuklarının televizyon karşısında daha fazla vakit geçirdiği ve bu ailelerin çocuklarıyla televizyondaki içeriklerle ilgili tartışmalara eğitim seviyesi yüksek ailelere göre daha az eğilim gösterdiği tespit edilmiştir (s. 53). Aynı araştırmada, pek çok çocuğun ebeveynlerinin müdahalesi olmadan televizyon izlediği ve 3-10 yaş aralığı gibi hassas bir yaş aralığında televizyondaki şiddete maruz kaldıkları elde edilen bulgular arasındadır (s. 53). Böylesi bir ortamda kitle iletişim araçlarının çocuklar üzerindeki etkisi üzerinde önemle durulan konular arasında yer almıştır.

1990'lı yıllarda medya içerikleri ve şiddet-saldırganlık arasındaki ilişki çeşitli çalışmalarda incelenmiştir. Örneğin, Brad J. Bushman ve Russel G. Geen şiddet içerikli filmleri izlemenin şiddet içermeyen filmleri izlemekten daha agresif düşüncelere yol açtığını göstermiştir. Yine Berkowitz, Parker ve West de benzer bir şekilde; savaş çizgi romanı okuyan çocukların, tarafsız bir çizgi roman okuyan çocuktan daha agresif anlamları olan sözcükleri seçme olasılıklarının daha yüksek olduğunu ortaya koyduklarını bir çalışma yapmıştır (Akt. Shrum, 1999, s. 77).

RTÜK’ün 2013 yllında “Türkiyede çocukların medya kullanma alışkanlıkları” konulu araştırmasına göre Türkiyede 26 ilde 6-18 yaş aralığındaki çocuklarla yapılan görüşmelerde çocuklara, "hayal güçlerinin gelişimi konusunda televizyondan etkilenip etkilenmedikleri" sorulmuş ve görüşme yapılan çocukların \%54,9'u televizyondan olumlu etkilendiğini, \%13,2'si olumsuz etkilendiğini ve $\% 31,9^{\prime} \mathrm{u}$ da etkilenmediğini belirtmiştir (s. 24).

Tüm bunların yanı sıra medya, çocukları ve gençleri yalnızca ev ödevi veya uykuda geçirdikleri zamanlarını almayıp aynı zamanda inanç ve davranışlarını da etkilemektedir. Sosyal öğrenme kuramına göre dikkatini dağıtmak için karartılmış bir odada bir televizyon ekranında modellenmiş eylemleri dikkatle izleyen çocuklar, sonrasında doğru taklitlerin ödüllendirildiğini görerek modellenen davranışlar için aynı miktarda taklit etme eylemi göstermektedir (Bandura, 1971, s. 9). Gülşah Sarı’nın (2018) İstanbul'da yaşayan 7-11 yaş aralı̆̆ındaki çocukların televizyon reklamlarıyla ilişkisini incelediği çalışmasında da televizyonda yer alan reklamların çocukların tüketimlerinde etkili olduğu tespit edilmiştir (s. 65).

Medyanın çocuğun hayatındaki rolünü inceleyen çok sayıda çalışma yapıldığını ve bu çalışmaların sonuçlarına göre kitle iletişim araçlarının en güçlü iletişim araçlarından biri olduğunu belirten Bahadır Köksalan, Ümit Ferit Aldım ve Şahin Göğebakan (2018), çocukların medya araçları sayesinde davranışlarını, tutumlarını ve dünya görüşlerini edindiklerini belirtmiş̧ir (s. 52).

Bu çalışmada, İstanbul ve Trabzon illerinde 3. ve 4. sınıfta okuyan 351 öğrencinin 15 Temmuz Darbe Girişimi’ni nasıl algıladıklarını çizdikleri resimler aracılığıyla belirlenmesi amaçlanmaktadır. Bu yaş aralığı çocukların çevresindeki olayları anlamlandırmaya başladığı yıllardır. Ayça Çamlıbel İrkin (2012), 7-11 yaş aralığındaki çocukların okuma, yazma ve sayısal işlem yetenekleriyle, dünyayı anlama ve mantıksal düşünme biçimlerinde önemli ilerlemeler gözlemlendiğini ve çocukların olayları diğer insanların gözünden görmeye başladığını ifade etmektedir (s. 45). 


\section{Çocukların Yaptı̆̆ı Resimlerdeki 15 Temmuz Darbe Girişimi Algısı}

Çalışmada verileri elde etmek adına İstanbul ve Trabzon illerindeki okulların belirlenmesi adına söz konusu illerin Milli Eğitim Müdürlüğü ve Kaymakamlıklarından gerekli izinler alınmıştır. Alınan izinler doğrultusunda izin verilen okullara ulaşılıp bu okullarda okuyan 3. ve 4. sınıf öğrencilerin sınıf öğretmenleriyle görüşülmüş ve çocuklardan resim dersinde, 1 ders saati süresince "15 Temmuz'u algıladıkları şekilde resmetmeleri” istenmiştir.

\section{Çalışmanın Yöntemi}

Çalışmanın evrenini İstanbul ve Trabzon’da ilkokul üç ve dördüncü sınıfta öğrenim gören 9-10 yaş grubu çocuklar oluşturmaktadır. Örneklem ise İstanbul Zeytinburnu’na bağlı Celalettin Gözüsulu İlköğretim Okulu ve Trabzon Arsin’e bağlı ilköğretim okullarının üç ve dördüncü sınıflarında okuyan 351 öğrencidir.

Çocukların 15 Temmuz Darbe Girişimi denildiğinde zihinlerinde oluşan algııı tespit etmek amacıyla yapılan bu alan araştırması 10-30 Mart 2018 tarihleri arasında yapılmıştır. Çocuk resimlerinin başlıca önemi, çocuğun düşünce şeklini ve içeriğini yansıtmasıdır. Çocuk bize resmiyle kendisinin bir parçasını yansıtmakta, olaylar hakkındaki duygu, düşünce ve görüş biçimlerini dile getirmektedir (Yavuzer, 1993). Bu nedenle her birinin farklı hayal ve algı dünyası olan çocukların 15 Temmuz'u nasıl yorumladıklarının tespit edilmesi için yaptıkları resimlerin incelenmesi oldukça önemlidir.

Çizim çalışmaları araştırmacıların zihinsel zeka, bilişsel yetenekleri ve çocukların sahip oldukları görsel hafızanın doğasını ve kapsamını incelemelerini sağlar (akt. Chan, 2006, s. 355). Çocukların çizdikleri şeyler; kişilikleri, tecrübeleri ve hisleriyle yakından ilişkilidir. Çocuğun yaptığı resimlerin; iç dünyasını yansıttığı, duyguların dışa vurumu olduğu, kişiliği ve psikolojik durumu hakkında fikir verdiği bilinmekte, çocuğun resimle fikir ve gözlemlerini görselleştirdiği düşünülmektedir (Malchiodiden akt. Gülerarslan, 2014, s. 137-138). Golomb’a göre ise çocuk resimlerinde kendisi için ne önemliyse onu ifade etmektedir (akt. McNeal ve Mindy, 2003, s. 404).

Bu anlamda ülkenin tümünü etkileyen 15 Temmuz Darbe Girişimi’ne ilişkin görüntülerden çoğunlukla çocukların da haberdar olduğu kabulünden hareketle yapılan bu araştırmada çocukların binlerce görüntü ve haber arasından kendince önemli olan görüntüleri resim olarak çizeceği varsayılmıştır. Toplam 351 çocukla yapılan bu çalışmada, çalışmaya dahil edilecek çocukların yaş aralığının belirlenebilmesi için toplam 70 öğrencisi bulunan Samsun Terme Ambertepe Eroğlu İlkokulu'nda pilot bir uygulama yapılmıştır. Birinci ve ikinci sınıftan toplam 29 çocuğun dahil edildiği alan araştırmasında 29 çocuktan 19'unun 15 Temmuz'u resmedemediği tespit edilmiştir. Bunun üzerine çalışmaya üçüncü ve dördüncü sınıf öğrencileriyle devam edilmiştir.

\section{Temmuz Darbe Girişimi Simgeleri}

15 Temmuz denildiğinde hemen herkesin aklına savaş uçakları, tank, darbe, şehit gibi oldukça önemli ve ağır kavramlar gelmektedir. Ancak çocukların ruh dünyası için bu kavramlar oldukça 
ağırdır. Gördükleri çoğu olumsuz görüntü çocukların bilinçaltında karanlık izler bırakırken, kaygı bozukluğu yaşamalarına da neden olabilmektedir. Dahası, Gürsoy Atar (2018) yaş arttıkça, çocukların veya gençlerin medya hakkında daha fazla bilgiye sahip olmaları ve medyaya yaklaşımlarının daha bilinçli olmasının muhtemel olduğunu söylemektedir (s. 146). Bu bağlamda 15 Temmuz Darbe Girişimi’nin çocuklar tarafından nasıl yorumlandığını, söz konusu haberleri kendi zihinsel süzgeçlerinden geçirip geçirmediklerini anlamak önem taşımaktadır.

Tablo 1. Katılımciların Sinıf ve Cinsiyeti

\begin{tabular}{|l|l|l|l|}
\cline { 2 - 3 } \multicolumn{1}{c|}{ Kiz } & Erkek \\
\hline 3. Sinif & 89 & 73 & \\
\hline 4. Sinif & 99 & 90 & 351 \\
\hline Toplam & 188 & 163 & \\
\hline
\end{tabular}

Tablo l'de yer alan $188 \mathrm{k}$ kz ve 163 erkek çocuğunun çizdiği resimlerden elde edilen veriler incelenirken çatı̧̧ma ve direnişi simgeleyen; tank, uçak, mermi, roket, silah öğelerini içeren halkın teröristlerle karşı karşıya geldiği resimler "Çatışmaya karşı koyan halk" kategorisinde değerlendirilmiştir. Bunun dışında saldırıya karşılık vermeyen halk "Saldırıya uğrayan halk" kategorisinde değerlendirilmiştir. Türk bayrağı ve 15 Temmuz kahramanlarının çizildiği resimler ise "Milli birlik ve beraberlik" kategorisinde incelenmiștir. "Simge noktaları" kategorisinde ise 15 Temmuz simgesi haline gelen yerler değerlendirilmiştir. "Kutlama, zafer" kategorisindeyse içinde Atatürk sözlerinin yer aldığı, halkın bayraklarla kutladığı resimler yer almıştır. Son olarak "Dini öğeler" kategorisinde ise camii ve minare resimleri yer almıştır.

\section{Temmuz Darbe Girişimi Denince Akla Gelen Konular}

351 çocuğun yaptığı resimler üzerinden 15 Temmuz Darbe Girişimi’ni nasıl anlamlandırdıklarının tespit edilmeye çalışıldığı çalışmada incelenen resimler 6 konu başlığı altında toplanmıştır. Resimlerin konulara göre dağılımı Tablo 2'de verilmiştir:

Tablo 2. Resimlerin Konulara Göre Dağılımı

\begin{tabular}{|l|l|l|l|}
\hline & Kız & Erkek & Toplam \\
\hline Çatışmaya karşı koyan halk & 85 & 62 & 152 \\
\hline Saldırıya uğrayan halk & 9 & 11 & 20 \\
\hline Milli birlik ve beraberlik & 40 & 32 & 72 \\
\hline Simge noktaları & 26 & 41 & 67 \\
\hline Kutlama, zafer & 21 & 6 & 27 \\
\hline Dini öğeler & 7 & 6 & 13 \\
\hline Toplam & $\mathbf{1 8 8}$ & $\mathbf{1 6 3}$ & $\mathbf{3 5 1}$ \\
\hline
\end{tabular}




\section{Çatışmaya Karşı Koyan ve Saldırıya Uğrayan Halk}

Sosyal öğrenme teorisine göre, çocuk doğduğu günden itibaren çevreyi gözlemler ve davranışlarını şekillendirir. Bir model olarak gözlemlediği davranışları benimser ve bu davranışları sosyal yaşamında kullanmaya başlar (Kalafat Çat, 2018, s. 258). Çalışmanın yukarısında yer alan Tablo 2 incelendiğinde toplam 152 çocuğun çatışmaya karşı koyan halkı resmettikleri görülmektedir. 20 resimde ise saldırıya maruz kalan, herhangi bir mücadelede bulunmayan halk tespit edilmiştir. Esasen incelenen diğer konu başlıklarında ele alınan resimlerin neredeyse hepsinde çatışmaya karşı koyan, direnen bir halktan söz etmek mümkündür. Ancak 15 Temmuz başlı̆̆ı altında belirginleşen birtakım öğelere resimlerde rastlandığı için bu resimlerin ayrı başlıklarda incelenmesi uygun görülmüştür. Çocuklar resimlerde saldıran tarafın asker olduğunu göstermek için eli silahlı çizdikleri erkek figürlerini yeşil renkle boyamışlardır. Bazıları ise insanları karşılıklı iki tarafa yerleştirip "iyi”, "kötü" şeklinde yazıyla ayırmıştır. Söz konusu resimlerin ortak özelliği, halkın hep birlikte darbe girişimini etkisiz hale getirmesi temasıdır.

\section{Milli Birlik ve Beraberlik}

15 Temmuz Darbe Girişimi’nin en temel belirleyenlerinden biri "milli birlik ve beraberlik duygusu” olmuştur. Darbe girişimini takip eden süreç analiz edildiğinde de bu hissiyatın vurgulandığı hatta sloganlar haline getirildiği görülmektedir. Bu durum geleneksel ve yeni medyada da gözlenmektedir. Nisan ve Şeker (2017), 15 Temmuz darbe girişiminin ardından Türk ulusal basının gazete sayfalarında darbe haberlerini nasıl çerçevelendiğini inceledikleri çalışmalarında, 16-22 Temmuz 2016 tarihleri arasındaki tüm ulusal gazetelerin birinci sayfalarını analiz etmişlerdir. Çalışmanın sonucunda toplam 170 haberde bu temanın işlendiği, darbe girişiminden sonra milletin darbeyi durdurmak için verdiği mücadele; kahramanlaştırma ve destanlaştırma, milli birlik ve beraberlik, milli duygular söylemleri üzerinden haberlerin inşa edildiği tespit edilmiştir. İncelenen resimlerde de 31 çocuğun tek başına çeşitli şekillerde Türk bayrağı resmi yaptığ dikkat çekmektedir. Bayrak resmi, "milli duygular” olarak yorumlanmaktadır. Türkiye’nin yaşadığı bu elzem olayı henüz anlamlandıramayacak yaşta olan çocukların, yaptığı resimlere bakıldığında çocukların medyada yer alan şeklini direk alarak egemen okuma yaptıkları gözlenmiştir.

Tablo 3’e bakıldığında 15 Temmuz simgeleri haline gelen "tankları durdurmaya çalışan halk"ın 40 çocuk tarafından resminin yapıldı̆̆ 1 görülmektedir. Halkın yaşlı, kadın, genç dinlemeksizin omuz omuza darbe girişimine engel olduğunu resmeden çocukların yaptığı çalışmalara örnek seçilen 4 resme yer verilmiştir. Örnekte yer alan resimlere bakıldığında medyaya belirginleşen öğelerin çocukların zihninde de yer ettiği görülmektedir.

Resim 1

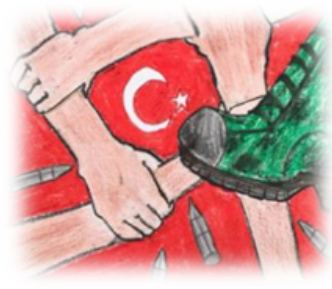

Resim 2

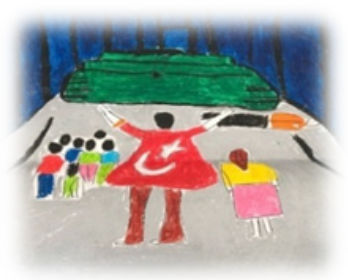

Resim 3

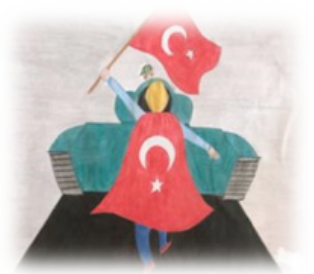

Resim 4

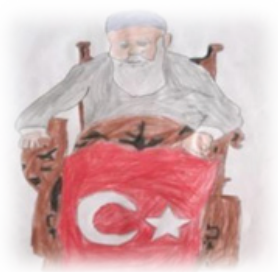


Benzer bir şekilde 9 çocuk, 15 Temmuz darbe girişiminin seyrini değiştiren ve darbeye karşı direnişin temsili haline gelen Astsubay Kıdemli Başçavuş Şehit Ömer Halisdemir’in resmini yapmıştır. Resimlere yapıldığında Ömer Halisdemir’in Türk bayrağı ile bütünleştirilerek destanlaştırıldığ 1 görülmektedir. Özellikle Resim 6'da 15 Temmuz’a dair çatışmanın temsili olan tankların önüne Ömer Halisdemir’in parmağını koyarak, halkı koruması kahramanlığa vurgu yapmaktadır.

Resim 5

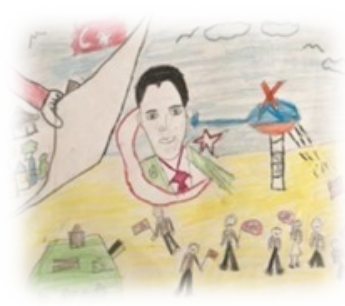

Resim 6

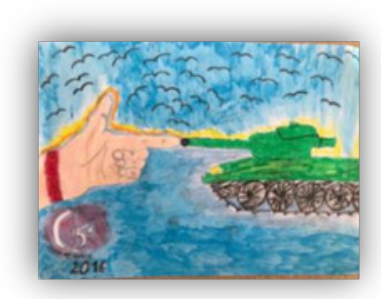

Destanlaştırma ve kahramanlaştırma mitleri içinde yer alan bu görüntüler çocukların zihinlerinde büyük yer edinmiştir. Zira bazı resimlere yazılan yazılar da bu tespiti desteklemektedir: "Bir ölür bin diriliriz", "15 Temmuz bir milletin dirilişi” ve "Hakimiyet milletindir”.

Yapılan resimlerde destanlaştırma ve kahramanlaştırma öğeleri içinde ilgi çekici bir bulguya ulaşılmıştır. Çalışmada iki çocuğun resmini yaptığı gözünden yaralanan bayrak tutan kahraman, 15 Temmuz gecesi Trabzon’un Yomra ilçesinde sivil bir FETÖ mensubunun silahından çıkan kurşunun gözüne isabet etmesi nedeniyle tek gözünü kaybeden Özdil Mahalle Muhtarı Barış Hatipoğlu’dur. Yomra, çalışmanın yapıldığı bölgelerden biri olan Arsin ilçesine $6 \mathrm{~km}$. uzaklıktadır. Ulusal medyada çok bahsi geçmeyen bu olayı resmeden iki çocuğun, yakınlarında olanlardan etkilendiği tespit edilmiştir. Çocukların aile ve etraflarından duyup, gördükleri olayların da zihinlerinde yer edindiği görülmektedir. Çocuklar, Ömer Halisdemir ve tankların önüne geçen halkın varlığından şüphesiz medya kanalıyla haberdar olmuşlardır. Gördüklerini anlayıp yorumlarken gerçeklik süzgecinden yeni yeni geçirmeye başlayan 9-10 yaş grubu çocuklar artık toplumun bir üyesi olduğundan haberdardır ve bu haberdar oluşu çizgilerine yansıtmaya başlamıştır (Yavuzer, 1993, s. 65).

Tablo 3. Milli birlik ve beraberlik duygusunun konulara göre dağılımı

\begin{tabular}{|l|c|c|c|}
\hline & Kız & Erkek & Toplam \\
\hline Bayrak & 19 & 12 & 31 \\
\hline Tankları durdurmaya çalışan halk & 16 & 14 & 40 \\
\hline Ömer Halis Demir & 4 & 5 & 9 \\
\hline Bir gözünü kaybeden muhtar & 1 & 1 & 2 \\
\hline Toplam & $\mathbf{4 0}$ & $\mathbf{3 2}$ & $\mathbf{7 2}$ \\
\hline
\end{tabular}

\section{Temmuz'un Simge Noktaları}

Darbe girişimi sırasında vatandaşların direniş gösterdiği mekânlar, çalışmada ayrı bir kategori olarak ele alınmıştır. Vatandaşların en çok direniş gösterdiği Boğaziçi Köprüsünün adı, "15 Temmuz 
Şehitler Köprüsü” olarak değiştirilmiştir. Köprü temalı 67 resim yapılmıştır. Çocukların yaptığı resimlerin arasından aşağıdaki iki resim örnek olarak seçilmiştir:

Resim 7

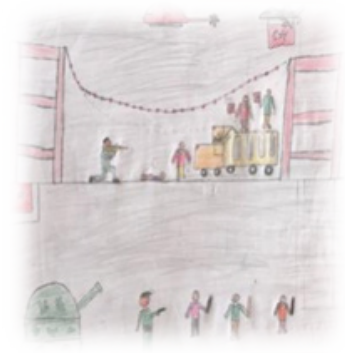

Resim 8

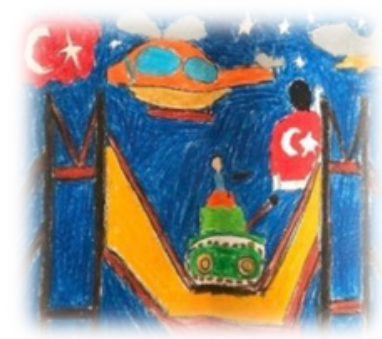

Şematik dönemden henüz çıarak gerçeklik dönemine giren çocuğun resimlerinde görülen mekan ile ilgili değişiklikler de önemli göstergelerdir. Artık çocuk, mekansal ilişkilerde belirli bir düzen ortaya koyabilmektedir (Yavuzer, 1993, s. 57). Örnek resimlerde de görüldügü gibi köprünün üzerinde tankı ve eli silahlı askeri durdurmaya çalışan Türk bayrağını giymiş, elinde bayrak tutan halk bulunmaktadır. Bir diğer ayrıntı tank ve askerin yeşil renkleriyle boyanmasıdır. Çocukların ekranlarda yer alan kamuflaj giymiş askerlerden etkilenerek bu resimleri yaptıklarını söylemek mümkündür. Zira yukarıdaki resimlerde içinde tank yer alan resimlerin hepsinde tank yeşil renktedir. Asker postalının milleti ezmeye çalıştı̆̆ birinci resimde yine postalın askere ait olduğunun belli olması için yeşil renkte boyanmıştır.

\section{Kutlama ve Zafer}

15 Temmuz Darbe Girişimi, Demokrasi ve Millî Birlik Günü ilan edilerek her yll 15 Temmuz’da kutlanan resmi bir tatil olarak düzenlenmiştir. Çalışmada 21 kız, 6 erkek çocuk 15 Temmuz konulu resimlerini şiddet ve çatışma öğelerinden uzak kutlama ve zaferi vurgulayarak yapmışlardır. $\mathrm{Bu}$ resimlerin çoğunluğunun kız çocukları tarafından yapılması dikkat çekmektedir. Kutlama konulu resimlerin temasını Türk bayrağı oluşturmaktadır. Bunlara örnek olarak seçilen resimler aşağıda yer almaktadır:

Resim 9

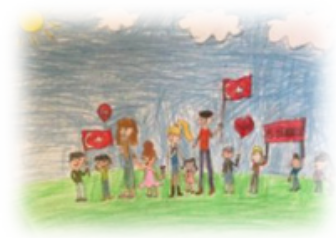

Resim 10

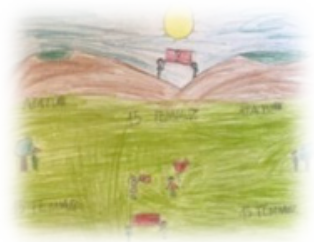

Resim 11

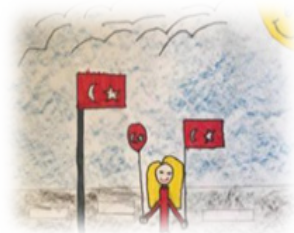

Resim 12

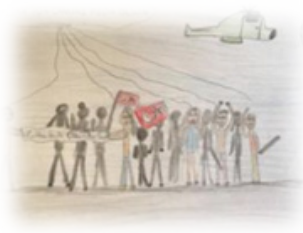

9, 10 ve 11 numaralı resimlere bakıldığında çocukların güneşin doğuşunun belirginleştiği gözlenmektedir. Gökyüzü mavi ve güneşli, mutluluk havası resmedilmiştir. 11 numaralı resimde çocuğun güneşe insan yüzü yaptığı dikkat çekmektedir. Esprili çizgilerle resme oyun karakteri 
vermek, çocuk resminin özellikleri arasındadır. Bu yüzden çocuk çiçeğe, güneşe insan yüzü yapar. Sezgici estetik yaklaşıma göre, çocuğun kendisini bir çeşit duygu sezgisiyle nesnenin yerine koyarak, kendi ile yaşantısı arasındaki uzaklık engelini kaldırıp biçimlendirdiği imgelerle ilgili düşüncelerini mecazlarla yansıtmaktadır (Yavuzer, 1993, s. 77). Bu anlamda kutlama yapan çocukların mutlu olduğunu söylemek mümkündür.

\section{Dini Öğeler}

15 Temmuz gecesinde darbe girişiminin ilk saatlerinde dönemin Diyanet İşleri Başkanı Mehmet Görmez'in Ülke TV'de canlı yayına katılarak ekrandan Türkiye'deki bütün din görevlilerini "sela ve ezan okumaya" davet etmesi üzerine (Öztürk, 2016) "cami ve minare" teması 15 Temmuz simgeleri arasında büyük bir yer edinmiştir. Böylelikle 15 Temmuz direnişini simgeleyen görüntülerde ülkenin ortak değeri bayrak ve ezan bir bütün olarak ele alınmıştır. Çalışmada incelenen 13 resmin dini öğeler içerdiği tespit edilmiştir. Örnek olarak seçilen resimler aşağıda verilmiştir. 13 numaralı resimde Arapça "Allahu Ekber" yazılı tekbir işareti ve minareye bağlanan Türk bayrağı görülmektedir. Bu resmin orijinali Hatay'in Reyhanlı ilçesindeki Şehit Bilal Kurtoğlu İmam Hatip Ortaokulu’nun iç duvarlarına çizilmişti (“15 Temmuz okul”, 2017). Medyaya yansıyan bu yağlı boya resimlerinden çocukların etkilendiği gözlenmiştir. Zira 13 numaralı resmin aynısı bir başka çocuk tarafından da yapılmıştır. Örnek iki resimde de minarelerdeki Türk bayrağı dikkat çekmektedir. Resim 14’te havadan ve karadan terörist askerlerin saldırdığı halk, bayrak ve ezanla bütünleşerek direnmiştir.

Resim 13

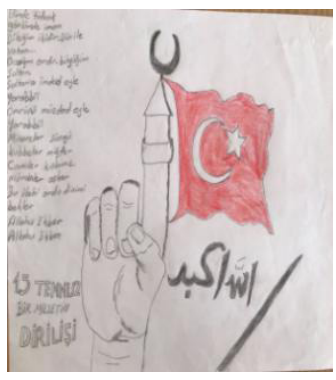

Resim 14

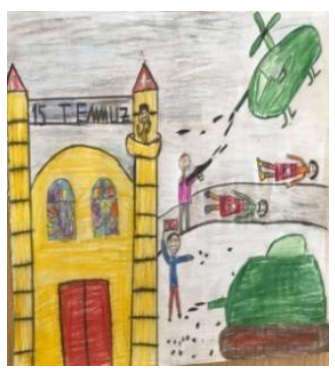

\section{Sonuç ve Değerlendirme}

Kitle iletişim araçlarının etkilerine yönelik yapılan çalışmalarda bahsedilen belki de en önemli nokta bu araçların toplumu şekillendirme ve eğitme işlevidir. Bilindiği gibi bu işlev kitle iletişim araçlarına büyük bir önem atfetmektedir. Ancak kitle iletişim araçlarında üretilen mesajların bir takım hâkim kültürel, ideolojik, ekonomik kodlar dolayımıyla üretildiği düşünüldüğünde söz konusu işlevin etkileri üzerinde durulmasındaki hakllık belirginleşmektedir. Bu anlamda kitle iletişim araçlarından özellikle televizyonun etkilerine yönelik yerli ve yabancı olmak üzere literatürde çeşitli çalışmalar yapılmaktadır. Yapılan çalışmalarda televizyonun çocukların tutum, davranış ve söylemlerini etkilediği vurgulanmıştır. 
Cesur ve Paker (2007) çocukların televizyonda en çok hangi programları izlediklerini tespit etmek için yurdun çeşitli illerinde yaşayan 454 ilkokul öğrencisine bir anket formu uygulamışlardır. Araştırmanın sonucunda, "çocukların çoğunlukla büyüklerin izledikleri programları izlediği” tespit edilerek, televizyonun çocuk dünyası ile yetişkin dünyası arasında olduğu varsayılan mesafeyi fiilen kaldırdığı belirtilmiştir (s. 122). Bu çalışmada da rastgele seçilen İstanbul Zeytinburnu’na bağlı Celalettin Gözüsulu İlköğretim Okulu ve Trabzon Arsin’e bağlı ilköğretim okullarının üç ve dördüncü sınıflarında okuyan 351 öğrencinin 15 Temmuz darbe girişimi konulu resimleri incelendiğinde, resimlerin kitle iletişim araçlarında sunulduğu şekliyle aktarıldığg gözlenmiştir. Bu sonuç Cesur ve Paker'in (2007) araştırmasında elde ettiği sonucu desteklemektedir.

Yine ülkemizde Radyo ve Televizyon Üst Kurulu (RTÜK) tarafından hazırlanan 2018 Nisan ayında İzleyici Bildirimleri ve Sektörel İstatistikler raporunda 13-16 yaş arası çocukların günlük televizyon izleme süresinin hafta içi ortalama 3 saat 34 dakika, hafta sonu ise 3 saat 59 dakika olduğunu belirtmiştir (s. 20). Bu oranlar göz önünde bulundurulduğunda kitle iletişim araçlarının çocuklar üzerindeki etkilerinin araştırılmasındaki önem belirginleşmektedir. Olayın yaşandığı süreç boyunca televizyon başta olmak üzere tüm kitle iletişim araçlarında neredeyse yayınlanan tek konu olan “15 Temmuz Darbe Girişimi”ne ait görseller şüphesiz çocuklara da ulaşmıştır. Zira çalışmada çizdirilen resimlerin incelenmesi sonucunda çocukların medyada gördükleri haber gibi çeşitli programlarda üretilen mesajları aynı şekilde resimledikleri tespit edilmiştir.

Çalışmanın literatür kısmında da belirtildiği gibi Tuncel ve Gürsoylar 2017 yılında İstanbul'da öğretim gören 13 yaşında, 66 öğrencinin resimleme yöntemiyle medya algılarını ölçmek istemiştir. Çalışmanın sonucunda yetişkin medyasının öğrenci algısını kuşattığı gözlenmiştir. Bu çalışmada da görüşülen öğrencilerin yaptıkları resimlerden kitle iletişim araçlarında yer alan 15 Temmuz konulu yayınları hakim okumayla alımladıkları tespit edilmiştir.

Köksalan, Aldım ve Göğebakan’ın (2018), çalışmalarında ele aldığı gibi medyanın çocuğun hayatındaki rolünü inceleyen araştırmaların neredeyse genelinde çocukların medya araçları sayesinde davranış ve tutumlarını edindikleri tespit edilmektedir (s. 52). Ancak çalışmada elde edilen bir diğer önemli bulgu medyanın yanı sıra çocukların yakın çevrelerinde gelişen olaylardan da benzer şekilde etkilendikleri yönündedir. Buna örnek olarak Trabzon'daki iki öğrencinin yakın çevrelerinde gördüğü "Özdil Mahalle Muhtarı Barış Hatipoğlu’nun sivil bir FETÖ mensubunun silahından çıkan kurşunun gözüne isabet etmesi nedeniyle tek gözünü kaybetmesini resmetmeleri” gösterilebilmektedir. Bu olay çocukların yakın çevrelerinde tanık oldukları olayları içselleştirip 15 Temmuz Darbe Girişimi’ni bu olay çerçevesinde yorumlamalarına işaret etmektedir.

Çalışmada elde edilen önemli bulgulardan bir diğeri, askerlerin çoğunlukla "kötü" tarafta resmedilmesi ve halkın birliktelik sergileyerek bunun önüne geçtiğidir. Zira örnek resimlerde de görüleceği gibi halkın birlikte mücadele ettiği grubun "karşısında" resmedilen kişiler askeri temsil eden yeşil renkle boyanmıştır. Aynı zamanda halkı ve birlikteliğin zaferine işaret eden resimlerin neredeyse hepsinde "bayrak" çizildiği tespit edilmiştir. Bir diğer ön plana çıkan sonuç, olayları artık mekânsal düzlem içerisinde tanımlayıp yorumlayan 9 ve 10 yaş grubundaki çocukların yaptığ 
resimlerin büyük kısmında “15 Temmuz Darbe Girişimi’nin Simge Noktaları” olarak kategorileştirilen ve olayların ağırlıklı olarak yaşandığı mekânların (15 Temmuz Köprüsü gibi) çizilmiş olmasıdır.

Çalışmanın sonucunda genel olarak çocukların 15 Temmuz Darbe Girişimi’ne ilişkin olayları yorumlarken sosyal çevrelerinden ve kitle iletişim araçlarından etkilendiği tespit edilmiştir. $\mathrm{Bu}$ anlamda çalışmadan elde edilen veriler geçmişten günümüze, kitle iletişim araçlarının etkileri konusunda yapılmış diğer çalışmaları destekler niteliktedir. İnsanlığın devamını sağlayabilmek için sağlıklı bir psikolojiyle yetişen çocukların önemi tartışlamaz bir gerçekliğe sahiptir. Bunun için çocukların bilincinde büyük bir yer edinen 15 Temmuz Darbe Girişimi gibi önemli olaylara dair etkilerin tespit edilmesi elzemdir. Bu çalışmanın alana katkı sağlamakla birlikte gelecek çalışmalara ş̧ık tutması beklenmektedir. 


\section{Kaynakça}

15 Temmuz okul duvarında. (2017, 3 Haziran). Artı Gerçek. 17.08.2018 tarihinde https://www.artigercek.com/ haberler/15-temmuz-okul-duvarinda adresinden erişilmiştir.

Atiker, E. (1998). Modernizm ve kitle toplumu. Ankara: Vadi Yayınları.

Balc1, F. ve Gergin, N. (2008). Medya ve çocuk: medyadaki şiddetin çocuklara etkisi. Y. Giritli İnceoğlu, N.Akıner (Ed). Medya ve çocuk rehberi içinde (ss. 145-170). Konya: Eğitim Kitabevi.

Bandura, A. (1971). Social learning theory. New York: General Learning Press.

Bektaş, A. (2000). Kamuoyu, iletişim ve demokrasi. İstanbul: Bağlam yayınevi.

Berelson, B. (2007). Communications and public opinion. İletişim Kuram ve Araştırma Dergisi, (24), 201-214.

Bernard-Bonnin, A., C., Gilbert, S., Rousseau. E., Masson, P., Maheux, B. (1991). Television and the 3 - to 10 year old child. Pediatrics, 88(1), 48-54.

Chan, K. (2006). Exploring children's perceptions of material possessions: a drawing study. Qualitative Market Research: An International Journal, 9(4), 352-366.

Cesur, S. ve Paker, O. (2007). Televizyon ve çocuk: Çocukların TV programlarına ilişkin tercihleri. Elektronik Sosyal Bilimler Dergisi, 6(19), 106-125.

Çamlıbel İrkin, A. (2012). Çocukların gelişim süreci ve televizyonun etkileri (Yayınlanmamış Uzmanlık Tezi). RTÜK, Ankara.

Dietz, W. H. Jr. ve Gortmaker, S. L. (1985). Do we fatten our children at the television set? Obesity and television viewing in children and adolescents. Pediatrics, 75(5), 807-812.

Erdoğan, İ. ve Alemdar, K. (2005). Öteki kuram: kitle iletişim kuram ve araştırmalarının tarihsel ve eleştirel bir değerlendirmesi. Ankara: Erk Yayınevi.

Gülerarslan, A. (2014). Reklamın çocukça anlamlandırılması. Selçuk Üniversitesi İletişim Fakültesi Akademik Dergisi, 8(2), 132-148.

Gürsoy Atar, Ö. (2018). Digital media literacy: In-depth interview with parents of the students who use digital media. Gülşah Sarı (Ed.). Handbook of research on children's consumption of digital media içinde (ss. 139155). ABD: Igi Global Yayınevi.

Halifeoğlu, M. (2015). Stuart Hall: Yapı, ideoloji, kültür. Hilal Onur-İnce (Ed). Günümüzde yeni siyasal yaklaşımlar III. eleştiriler-farklılıklar-çözüm arayışları içinde (ss. 231-257). Ankara: Doğu Batı Yayınları.

Hall, S. (1999). Encoding/decoding. Simon During (Ed). The cultural studies reader içinde (ss. 90-103). Psychology Press.

Hall, S. (2003), “Kodlama ve kodaçım”, Söylem ve İdeoloji İçinde, B. Çoban ve Z. Özarslan (Der.). (ss. 309-325). İstanbul: Su Yayınları.

Hall, S. (2005). Kodlama, kodaçımlama. Ş.Yavuz (Ed.), Medya ve izleyici bitmeyen tartışma içinde (ss. 85-98), (Çev.Y. Yavuz). Ankara: Vadi Yayınevi.

Işık, M. (2017). İletişim bilimine giriş. Konya: Eğitim Yayınevi.

İnal, M. A. (1996). Haberi okumak. İstanbul: Temuçin Yayınevi.

Kalafat Çat, A. (2018). Digital games and violance. Gülşah Sarı (Ed.). Handbook of research on children's consumption of digital media içinde (ss. 258-275). ABD: Igi Global.

Katz, E. ve Lazarsfeld, P. (2007). Personal influence. İletişim Kuram ve Araştırma Dergisi, (24), 271-280.

Katz, E. (1987). Communications research since Lazarsfeld. Public Opinion Quarterly, 51(4 Part 2), 25-45.

Kellner, D. (2016). Kültürel Marksizm ve kültürel çalışmalar, Fatih Tezcan (Çev.), ETHOS: Felsefe ve Toplumsal Bilimlerde Diyaloglar, 9(2), 132-151. 
Korkmaz, N. ve Yaylagül, L. (2008). Kitle Kültürü/ Popüler Kültür Tartışmaları, L. Yaylagül ve N. Korkmaz (Der). Medya, popüler kültür ve ideoloji içinde (ss. 125 - 139). Ankara: Dipnot Yayınları.

Köksalan, B., Aldım, U. F. ve Göğebakan, Ş. (2018). Media consuming in children: child development, babyhood (0-2), early childhood, interests. Gülşah Sarı (Ed.) Handbook of Research on Children's Consumption of Digital Media içinde (ss. 41-49). ABD: IGI Global yayınevi.

Lazarsfeld, P. ve Merton, R.K. (2007). Mass communication, popular taste, and organized social action. İletişim Kuram ve Araştırma Dergisi, 24, 229-250.

Mares, M. L. ve Kretz, V. (2015, 20 Ekim). 09.08.2018 tarihinde http://scitechconnect.elsevier.com/mediachildrens-social-moral-development/ adresinden erişilmiştir.

McNeal, J. U. ve Mindy, F. J. (2003). Children's visual memory of packaging. Journal of Consumer Marketing 20(5), 400-427.

Nisan, F. ve Şeker, T. (2017). Demokrasiyi sekteye uğratan darbe haberlerinin çerçevelenmesi: 15 Temmuz 2016 darbe girişimi örneği. TRT Akademi, 2(3), 68-96.

Öcel, N. (2002). İletişim ve çocuk, “ İletişim ortamlarında çocuk reklam ve etkileşimi”. İstanbul: İstanbul Üniversitesi İletişim Fakültesi Yayınları.

Öztürk, H. (2016, 13 Kasım). 15 Temmuz gecesi sela ve ezan fikri kimindi? Yeni Şafak. 17.08.2018 tarihinde https:// www.yenisafak.com/yazarlar/hasanozturk/15-temmuz-gecesi-sela-ve-ezan-fikri-kimindi-2034098 adresinden erişilmiştir.

Postman, N. (1995). Çocukluğun yokoluşu. K. İnal (Çev). Ankara: İmge Yayınevi.

RTÜK (2013). Türkiye’de çocukların medya kullanma alışkanlıkları araştırması. İstanbul: Bizim Matbaa.

RTÜK (2018). İzleyici bildirimleri ve sektörel istatistikler, Kamuoyu Yayın Araştırmaları ve Ölçme Dairesi Başkanlığı,https://www.rtuk.gov.tr/assets/Icerik/AltSiteler/2018yilinisanayivatandasbildirimleriraporu. pdf adresinden 09.08.2018 tarihinde elde edilmiştir.

Rubin, A. M. (2009). “The uses and gratifications perspective of media effects”, Bryant, J. \& Oliver, M. B. (Ed.), Media effects: advances in theory and research içinde (ss. 525-548). London: Routledge.

Sarı, G. (2018). Effects of ads on children's consumption behavior. Süleyman Demirel Üniversitesi Vizyoner Dergisi, 9(20), 53-67.

Shrum, L. J. (2009). Media consumption and perceptions of social reality: effects and underlying processes, J. Bryant ve M. B. Oliver (Ed.), Media effects: Advances in theory and research içinde (ss. 39-95). Routledge Yayınevi.

Stevenson, N. (2008). Medya kültürleri: sosyal teori ve kitle iletişimi. Ankara: Ütopya Yayınevi.

Şakı Aydın, O. (2007). Alımlama araştırmaları ve kültürel çalışmalar geleneğinin katkısı. İstanbul Ticaret Üniversitesi Sosyal Bilimler Dergisi, 6(11), 119-131.

Şeker, T. ve Sine, R. (2012). Çocuk zihnindeki haber resmi. Global Media Journal, Spring, 4(2), 118-137.

Şeker, N. T. ve Balcı, V. E. (2013). Yeni Türk dizi fenomeni "Pepee” çizgi dizinin alımlama analizi. Selçuk Üniversitesi Türkiyat Araştırmaları Enstitüsü Türkiyat Araştırmaları Dergisi, (33), 243-263.

Şimşek İşliyen, F. ve İşliyen, M. (2015). Çocukların medya algısının resimler üzerinden analizi. Global Media Journal: Turkish Edition, 5(10), 271-287.

Taylan, H. H. (2011). Televizyonla yetişmek: televizyon şiddetinin etkileri üzerine bir araştırma. Konya: Çizgi yayınevi.

Tekinalp, Ş. ve Uzun, R. (2013). İletişim araştırmaları ve kuramları. İstanbul: Beta Yayınevi.

Tombul, I. (2018). Rethinking e-learning and digital natives. Gülşah Sarı (Ed.). Handbook of research on children's consumption of digital media içinde (ss. 114-124). ABD: Igi Global. 
Tuncel, G. ve Gürsoylar, G. (2017). Sosyal bilgiler dersinde öğrencilerin gözüyle medya: Sanat temelli bir araştırma. Akademik Sosyal Araştırmalar Dergisi, 5(44), 655-674.

Türkoğlu, N. (2010). İletişim bilimlerinden kültürel çalışmalara toplumsal iletişim: tanımlar, kavramlar, tartışmalar. İstanbul: Urban Yayınevi.

Yaylagül, L. (2008). Kitle iletişim kuramları. Ankara: Dipnot Yayınları.

Yaylagül, L. (2008). Frankfurt Okulu’nda "kültür endüstrileri” ve "kitle kültürü" yaklaşımı, L. Yaylagül ve N. Korkmaz (Der). Medya, popüler kültür ve ideoloji içinde (ss. 139-155). Ankara: Dipnot Yayınları.

Yavuzer H. (1993). Resimleriyle çocuk. İstanbul: Remzi Kitabevi.

Yetim, N. ve Yetim, Ü. (2008). Medya temsillerinde özne ve nesne olarak çocuk. Y. Giritli İnceoğlu, N.Akıner (Ed). Medya ve Çocuk Rehberi içinde (ss. 89-114). Konya: Eğitim Kitabevi.

Yıldı, S. (2017). Medya ve hukuk. İstanbul: Nobel Yayınevi.

Yurtal, F. ve Artut, K. (2008). Çocukların şiddeti algılama biçimlerinin çizdikleri resimlerine yansımaları. Çocuk ve Gençlik Ruh Sağlı̆̆ı Dergisi, 15(3), 149-155. 